\title{
COFFEE YIELD AND PHOSPHATE NUTRITION PROVIDED TO PLANTS BY VARIOUS PHOSPHORUS SOURCES AND LEVELS
}

\author{
Produtividade e nutrição fosfatada de cafeeiros submetidos \\ a fontes e doses de fósforo
}

\author{
Kaio Gonçalves de Lima Dias ${ }^{1}$, Antônio Eduardo Furtini Neto ${ }^{2}$, Paulo Tácito Gontijo Guimarães ${ }^{3}$, \\ Thiago Henrique Pereira Reis ${ }^{2}$, Cesar Henrique Caputo de Oliveira ${ }^{2}$
}

\begin{abstract}
Phosphorus (P) is considered one of the nutrients that most limits crop yields, especially in soils with an advanced degree of weathering. To evaluate $\mathrm{P}$ dynamics and availability in soil resulting from various $\mathrm{P}$ doses and sources and to assess the resulting P content of coffee leaves and the final coffee yield, an experiment was conducted in the municipality of Três Pontas, MG, Brazil, in a Red Argisol (Ultisol) area. Fertilization, except for P fertilization, was performed based on the soil analysis results. The annual $\mathrm{P}$ doses tested were $0,75,150,300,450$ and $600 \mathrm{~kg} \mathrm{ha}^{-1} \mathrm{P}_{2} \mathrm{O}_{5}$. Two $\mathrm{P}$ sources, simple superphosphate and magnesium thermal phosphate, were evaluated and compared in the study. A physicochemical analysis of the soil and an analysis of leaf dry matter were performed. The available $\mathrm{P}$ content in the soil increased as a result of the applications of the two sources. The leaf $\mathrm{P}$ levels stabilized at approximately 1.8 and $1.9 \mathrm{~g} \mathrm{~kg}^{-1}$ for simple superphosphate and magnesium thermal phosphate, respectively, as a result of the application of approximately $300 \mathrm{~kg} \mathrm{ha}^{-1} \mathrm{P}_{2} \mathrm{O}_{5}$. The coffee responded to $\mathrm{P}$ fertilization in the production phase. Averaged over three harvests, the yield per harvest showed gains of $45.3 \%$ and $40.3 \%$ for simple superphosphate and magnesium thermal phosphate, respectively, with the application of the highest studied dose, $600 \mathrm{~kg} \mathrm{ha}^{-1} \mathrm{P}_{2} \mathrm{O}_{5}$.
\end{abstract}

Index terms: Coffee nutrition; Coffea arabica; phosphorus fertilization.

\section{RESUMO}

O fósforo tem sido apontado como um dos nutrientes mais limitantes ao rendimento das culturas, principalmente em solos com avançado grau de intemperísmo. Com objetivo de avaliar a dinâmica e disponibilidade de P, teores foliares de P e a produtividade do cafeeiro em função da aplicação de doses e fontes de $\mathrm{P}$, foi instalado um experimento no município de Três Pontas - MG, em uma área de um Argissolo Vermelho. As adubações foram realizadas levando em consideração o resultado da análise de solo, exceto para

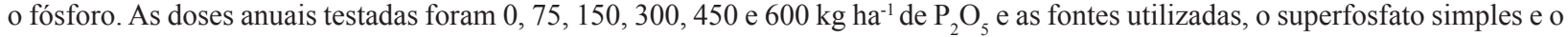
termofosfato magnesiano. Procedeu-se analise físico-química do solo e análise de matéria seca das folhas. Os teores de P disponível no solo aumentaram pela aplicação das duas fontes, assim como os teores foliares de $\mathrm{P}$, que se estabilizaram em torno de 1,8 e 1,9 $\mathrm{g} \mathrm{kg}^{-1}$, com a aplicação de aproximadamente $300 \mathrm{~kg} \mathrm{ha}^{-1} \mathrm{de}_{2} \mathrm{O}_{5}$. $\mathrm{O}$ cafeeiro mostrou-se responsivo à adubação fosfatada na fase de produção, obtendo-se na média de três safras, ganhos de 45,3 e 40,3\%, para o superfosfato simples e termofosfato magnesiano, respectivamente, com a aplicação da maior dose estudada de $600 \mathrm{~kg} \mathrm{ha}^{-1}$ de $\mathrm{P}_{2} \mathrm{O}_{5}$.

Termos para indexação: Nutrição do cafeeiro; Coffea arabica; adubação fosfatada.

\section{INTRODUCTION}

Brazil is the largest producer and exporter of coffee, with 2012 domestic production estimated at 50.83 million bags. The state of Minas Gerais is the leading producer, with most production based in the Southern Region of the state (National Supply Company - CONAB, 2013). This mountainous region has focused its production on quality coffees, taking advantage of its markedly different climatic characteristics and adding value to the product harvested. In addition to its economic benefits for producers and for the national trade balance, coffee is also highly important from a social perspective. Indeed, coffee production demands a substantial amount of labor throughout its supply chain, especially in regions with extremely uneven topographic relief.

Until the 60s, Brazilian coffee plantations were sited in areas of average to high fertility that were originally forested. With the tightening of environmental legislation and the increased cost of the most fertile areas, coffee culture has expanded into areas that were marginal in terms of fertility, where constant soil correction and fertilization are needed. These soils, generally weathered and oxidic, represent major phosphorus (P) sinks (Novais et al., 2007).

\footnotetext{
1Universidade Federal de Lavras/UFLA - Departamento de Ciência do Solo/DCS - Cx. P. 3037 - 37200-000 - Lavras - MG - Brasil - kaiogld@gmail.com 2Universidade Federal de Lavras/UFLA - Departamento de Ciência do Solo/DCS - Lavras - MG - Brasil

${ }^{3}$ Empresa de Pesquisa Agropecuária de Minas Gerais/Epamig - Campus UFLA - Lavras - MG - Brasil

Received in july 3, 2014 and approved in november 3, 2014
}

Ciênc. Agrotec., Lavras, v.39, n.2, p.110-120, mar./abr., 2015 
As a nutrient, $P$ has been extensively investigated due to its importance to life, its frequent role as a limiting factor in crop production and its identity as a finite and irreplaceable mineral resource (Malavolta, 2006). It is the nutrient that most commonly limits crop production in Brazil (Caione et al., 2012). Fertilization with P fertilizers is needed to obtain good yields (Nachimuthu et al., 2009) sice most Brazilian soils naturally present a low $\mathrm{P}$ content.

For many years, the coffee plant was not considered to be responsive to $\mathrm{P}$ maintenance through fertilization (Bataglia, 2004). Most likely, the basis of this statement is that $\mathrm{P}$ is a macronutrient that is both required and exported only in small quantities by the coffee crop (Guimarães et al., 2011). Previous research has demonstrated that coffee responds well to $\mathrm{P}$ fertilization. However, few studies of coffee have investigated the use of different sources of $\mathrm{P}$ in maintenance applications for fertilization.

The purpose of this paper was to evaluate the effects of maintenance through fertilization with increasing doses of $\mathrm{P}_{2} \mathrm{O}_{5}$ as simple superphosphate and magnesium thermal phosphate in coffee plantations in southern Minas Gerais.

\section{MATERIALS AND METHODS}

The experiment was initiated in 2008 on a clayey Red Argisol (Ultisol) at the EPAMIG Experimental Farm located in the city of Três Pontas, MG, in an area planted with the Catiguá MG-2 cultivar. The experimental area is located at $21^{\circ} 20^{\prime} 38^{\prime \prime} \mathrm{S}, 45^{\circ} 28^{\prime} 48^{\prime \prime} \mathrm{W}$ at an altitude of $940 \mathrm{~m}$.

The climate is Cwa type with Cwb characteristics, with two defined seasons: a dry season (April to September) and a wet season (October-March) according to the Köppen climate classification.

The crop was planted in February 2004 at a spacing of $3.60 \times 0.60 \mathrm{~m}$ with one plant per hole. The fertilization conducted at planting was $550 \mathrm{~kg} \mathrm{ha}^{-1}$ of limestone, $166 \mathrm{~kg} \mathrm{ha}^{-1} \mathrm{P}_{2} \mathrm{O}_{5}$ as simple superphosphate, $280 \mathrm{~kg} \mathrm{ha}^{-1}$ corral manure and $140 \mathrm{~kg} \mathrm{ha}^{-1} \mathrm{~N}$ and $\mathrm{K}_{2} \mathrm{O}$ as a $20-00-20$ formulation, parceled out in three applications in the first year after planting.
From the second year until the test installation, fertilizations were conducted according to Guimarães, Ribeiro e Alvarez (1999) without new P applications; foliar spraying was performed when necessary using $1.5 \mathrm{~kg} \mathrm{ha}^{-1}$ of zinc sulfate, boric acid, manganese sulfate, potassium chloride and copper oxychloride.

In early 2008, prior to the experiment, soil samples were taken at a depth of 0 to $0.2 \mathrm{~m}$ to obtain a chemical and physical characterization of the area (Table 1). Culture and phytosanitary treatments were the same for all treatments and followed the management practices adopted on the property. Fertilization continued to be performed according to Guimarães, Ribeiro e Alvarez (1999) based on the results of the soil analysis except that no fertilization was performed for phosphorus.

In 2009 , liming was performed by applying 1.5 $\mathrm{t} \mathrm{ha}^{-1}$ of calcitic limestone with $100 \%$ RTNP under the projection of the coffee canopy, Lime was not reapplied in the other years. Treatments consisted of manual applications of six $\mathrm{P}$ doses from two sources as follows: 0 (control), 75, 150, 300, 450 and $600 \mathrm{~kg} \mathrm{ha}^{-1} \mathrm{P}_{2} \mathrm{O}_{5}$ as simple superphosphate or as magnesium thermal phosphate. The $P$ sources were not enriched with micronutrients. The other nutrients were at sufficient levels for coffee growth.

A randomized block experiment in a $6 \times 2$ factorial design was used. Five replicates were performed with ten plants per plot. The eight central plants in the plot were evaluated. Treatments were applied manually at the same time at the beginning of the rainy season (October) and reapplied annually during the same period.

The evaluation of the mineral nutrition of the crop was accompanied by analyses of leaf samples collected before the grain filling stage. Soil samples from below the projection of the canopy of the coffee plants were collected at depths of 0 to 0.1 and 0 to $0.2 \mathrm{~m}$. The samples were always collected after the harvest and before the annual application of the treatments. Composite soil samples were collected using an auger and were removed from different points for each depth, maintaining the independence of the soil layers. For the analysis of the plant material, leaves were collected from the middle third of the plants from the third or fourth leaf pairs on a plagiotropic branch.

Table 1: Chemical and physical properties of a Red Argisol (Ultisol) at a depth of 0-0.2 m, EPAMIG, Três Pontas, MG.

\begin{tabular}{|c|c|c|c|c|c|c|c|c|c|c|c|c|}
\hline $\mathrm{pH}$ & $\mathrm{K}$ & $\mathrm{P}$ & P-rem & $\mathrm{Ca}$ & $\mathrm{Mg}$ & $\mathrm{Al}$ & $\mathrm{H}+\mathrm{Al}$ & $\mathrm{M}$ & O.M. & Sand & Silt & Clay \\
\hline $\mathrm{H}_{2} \mathrm{O}$ & \multicolumn{3}{|c|}{------ mg dm ${ }^{-3}$------- } & \multicolumn{4}{|c|}{------cmol $\mathrm{dm}^{-3}$------ } & $\%$ & dag $\mathrm{kg}^{-1}$ & \multicolumn{3}{|c|}{-----------g kg-1--------- } \\
\hline 5.6 & 184 & 8.2 & 26.4 & 2.6 & 0.7 & 0.1 & 3.2 & 3 & 2.1 & 280 & 320 & 400 \\
\hline
\end{tabular}


The soil chemical characterization $(\mathrm{pH}, \mathrm{K}, \mathrm{Ca}, \mathrm{Mg}$, $\mathrm{Al}, \mathrm{H}+\mathrm{Al}$, $\mathrm{P}$, remaining-P) was conducted according to the methodology of the Brazilian Agricultural Research Corporation - EMBRAPA (2009). Two separate methods, Mehlich-1 extraction (EMBRAPA, 2009) and an ion exchange resin (Raij et al., 2001) were used to determine the soil P content. The methods described in Malavolta, Vitti e Oliveira (1997) were used to determine the nutrient levels in leaf dry matter.

The efficiency of the $\mathrm{P}$ sources was evaluated relative to that of the soluble source by calculating the Agronomic Efficiency Index (AEI) described by Chien e Hammond (1978): AEI (\%) = 100 (Pn - P0) / (PSFT - P0), where $\mathrm{Pn}=$ the yield obtained from a dose $\mathrm{n}$ of the source, $\mathrm{P} 0=$ the production obtained from the control $\left(0 \mathrm{mg} \mathrm{kg}^{-1}\right.$ $\mathrm{P})$ and PSFT $=$ yield from the soluble source at a dose $n$.

For the calculation of production at maximal economic efficiency, a dose equivalent to $90 \%$ of the maximum physical production was used (Alvarez, 1996). The production of the plots in 2009, 2010 and 2011 were measured and the yields from different treatments evaluated. Harvesting was performed by hand above a piece of cloth placed below the harvesting point.

The data were subjected to an analysis of variance. Regression equations were fitted to the data to assess the $\mathrm{P}$ content of the soil, the $\mathrm{P}$ content of the plant and productivity. Tests of means (F test, 5\% significance) were also conducted to evaluate the effect of the sources. All analyses were performed using the SISVAR statistical program (Ferreira, 2011).

\section{RESULTS AND DISCUSSION}

\section{Soil phosphorus}

At the end of the three-year evaluation period, we observed increases in the soil available P level as determined by the Mehlich-1 extractant and by the ion exchange resin (Figures 1 and 2). The highest $P$ concentrations were observed at the depth of 0 to $0.1 \mathrm{~m}$ in 2011 due to the low soil mobility of $\mathrm{P}$ and the reapplication of the annual treatments. According to Conte, Anghinoni e Rheinheimer (2003), P adsorption occurs primarily at the sites having the greatest chemical stability. Subsequently, the nutrient is redistributed into fractions that require less energy to retain and that are more available to the plants. Most likely, the increase in soil available $\mathrm{P}$ was due to the saturation of the adsorption sites that offer greater chemical stability, subsequently increasing the availability of this nutrient, with possible consequences for the foliar nutrient content and for plant productivity.
Note that for this soil (clayey), the levels of extracted $\mathrm{P}$ at a depth of 0 to $0.2 \mathrm{~m}$ that are considered to be very good are $13.5 \mathrm{mg} \mathrm{dm}^{-3}$ if Mehlich-1 extraction is used (Guimarães et al., 1999) and $30 \mathrm{mg} \mathrm{dm}^{-3}$ if the ion exchange resin is used (Raij et al., 1997). According to these recommendations, the application of 0 or $20 \mathrm{~kg}$ ha $^{-1} \mathrm{P}_{2} \mathrm{O}_{5}$, according to Guimarães et al. (1999) and Raij et al. (1997), respectively, would be required for a yield of $50 \mathrm{bags}$, each containing $60 \mathrm{~kg}$ of processed coffee $\mathrm{ha}^{-1}$. If the doses ( 0 or $20 \mathrm{~kg} \mathrm{ha}^{-1} \mathrm{P}_{2} \mathrm{O}_{5}$ ) recommended by these authors are substituted in the estimated average production equation for the three years 2009-2010-2011, the following yields are obtained: yields of 42.7 and 43.3 bags $\mathrm{ha}^{-1}$ are obtained for simple superphosphate and magnesium thermal phosphate, respectively, if a dose of $0 \mathrm{~kg} \mathrm{ha}^{-1} \mathrm{P}_{2} \mathrm{O}_{5}$ is used (Guimarães et al., 1999); yields of 43.5 and 44.0 bags ha $^{-1}$ are obtained for simple superphosphate and magnesium thermal phosphate, respectively, if a dose of $20 \mathrm{~kg} \mathrm{ha}^{-1} \mathrm{P}_{2} \mathrm{O}_{5}$ is used (Raij et al., 1997). These expected yields are all less than 50 bags $\mathrm{ha}^{-1}$. Furthermore, these values are less than the average yield per harvest, averaged over three harvests, of 58.4 and 56.4 bags ha $^{-1}$ obtained with the application of $600 \mathrm{~kg} \mathrm{ha}^{-1}$ $\mathrm{P}_{2} \mathrm{O}_{5}$ as simple superphosphate and magnesium thermal phosphate, respectively. These results demonstrate a need to adopt updated criteria for the recommended phosphorus fertilizer applications for the coffee crop.

A study by Correa et al. (2001) examined coffee crop samples collected in southern Minas Gerais. Those authors found that $37.3 \%$ and $34.7 \%$ of the evaluated crops showed a low and an average $\mathrm{P}$ content, respectively. In view of the finding by the present study that the highest yields were obtained at levels well above those considered adequate by those authors, it is assumed that this nutrient may be limiting productivity in most of the coffee crops in the region.

The determination of remaining phosphorus (P-rem) yields a measure of the amount of $\mathrm{P}$ that remains in equilibrium in solution in response to the concentration of $\mathrm{P}$ added to the soil. Increases in the P-rem values (Figure 3) indicate a possible saturation of a part of the soil adsorption sites or a decrease in the "binding energy" of the soil P described by Novais et al. (2007), increasing the $P$ content remaining in solution and therefore available to coffee. The behavior of P-rem as a function of the dose appears to be gradual because the response of this variable to the applied doses was quadratic, tending to stabilize with increases in the applications of each of the two sources (Figures 3A and 3B), except in 2011, when this behavior was linear (Figure 3C). 

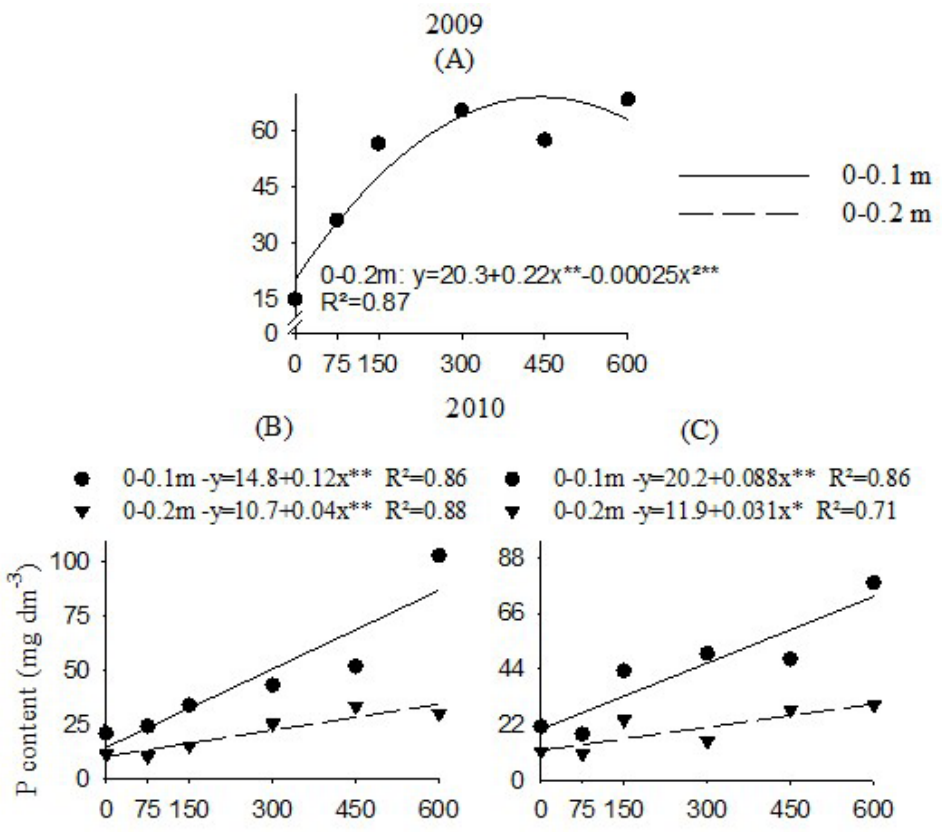

- $0-0.1 \mathrm{~m}-\mathrm{y}=20.2+0.088 \mathrm{x}^{* *} \mathrm{R}^{2}=0.86$ $0-0.2 \mathrm{~m}-\mathrm{y}=11.9+0.031 \mathrm{x}^{*} \mathrm{R}^{2}=0.71$

(D)

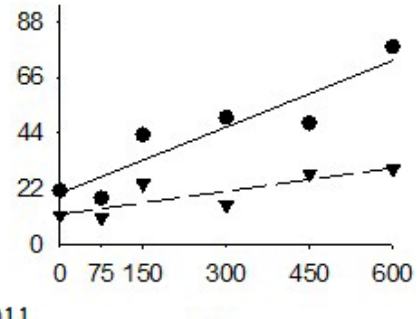

2011

(E)

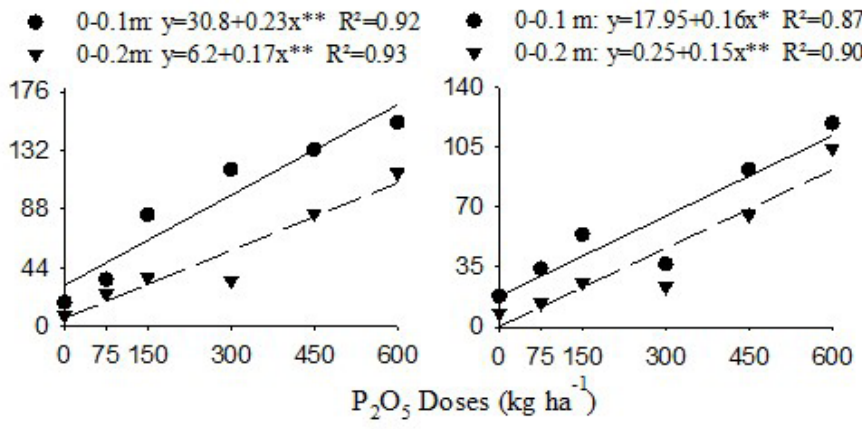

Figure 1: Soil available P measured by Mehlich-1 extraction at depths of 0-0.1 $\mathrm{m}$ and 0-0.2 $\mathrm{m}$ in a Red Argisol (Ultisol) of Três Pontas, MG, as a function of the annual surface applications of sources and doses of phosphorus in samples collected during 2009, 2010 and 2011. A, B and D: simple superphosphate source; C and E: thermal phosphate source. Significant (t-test) at $* 5 \%$ and $* * 1 \%$.

\section{Leaf $P$ content}

The P content in 2009 increased linearly only for simple superphosphate (Figure 4A). In 2010 and 2011, an exponential increase in the $\mathrm{P}$ content occurred for both sources (Figures 4B, 4C and 4E). The response was quadratic only for simple superphosphate for the last year (Figure 4D). Additionally, leaf P content at the same dose increased with plant age (Figure 4). It is probable that this increase reflected a saturation of a part of the adsorption sites due to the annual reapplication of treatments, as observed for the P-rem values (Figure 3).
The levels of $\mathrm{P}$ increased significantly, beginning with the dose of $75 \mathrm{~kg} \mathrm{ha}^{-1} \mathrm{P}_{2} \mathrm{O}_{5}$, with a tendency to stabilize at approximately 1.8 to $1.9 \mathrm{~g} \mathrm{~kg}^{-1}$ starting at the $300 \mathrm{~kg} \mathrm{ha}^{-1}$ dose. However, the yields showed this behavior only in 2009 and in the 2009-2010 biennium production for magnesium thermal phosphate (Figures 5B and 5D). In the other years, the yields were linear (Figures 5A, 5C and 6). These findings show that the energy demand of the coffee plant was high when the high yields were obtained. The reason for this high energy demand was that the treatments with high yields, which also received the highest $\mathrm{P}$ doses, produced greater vegetative growth and/or higher extraction. Similar 


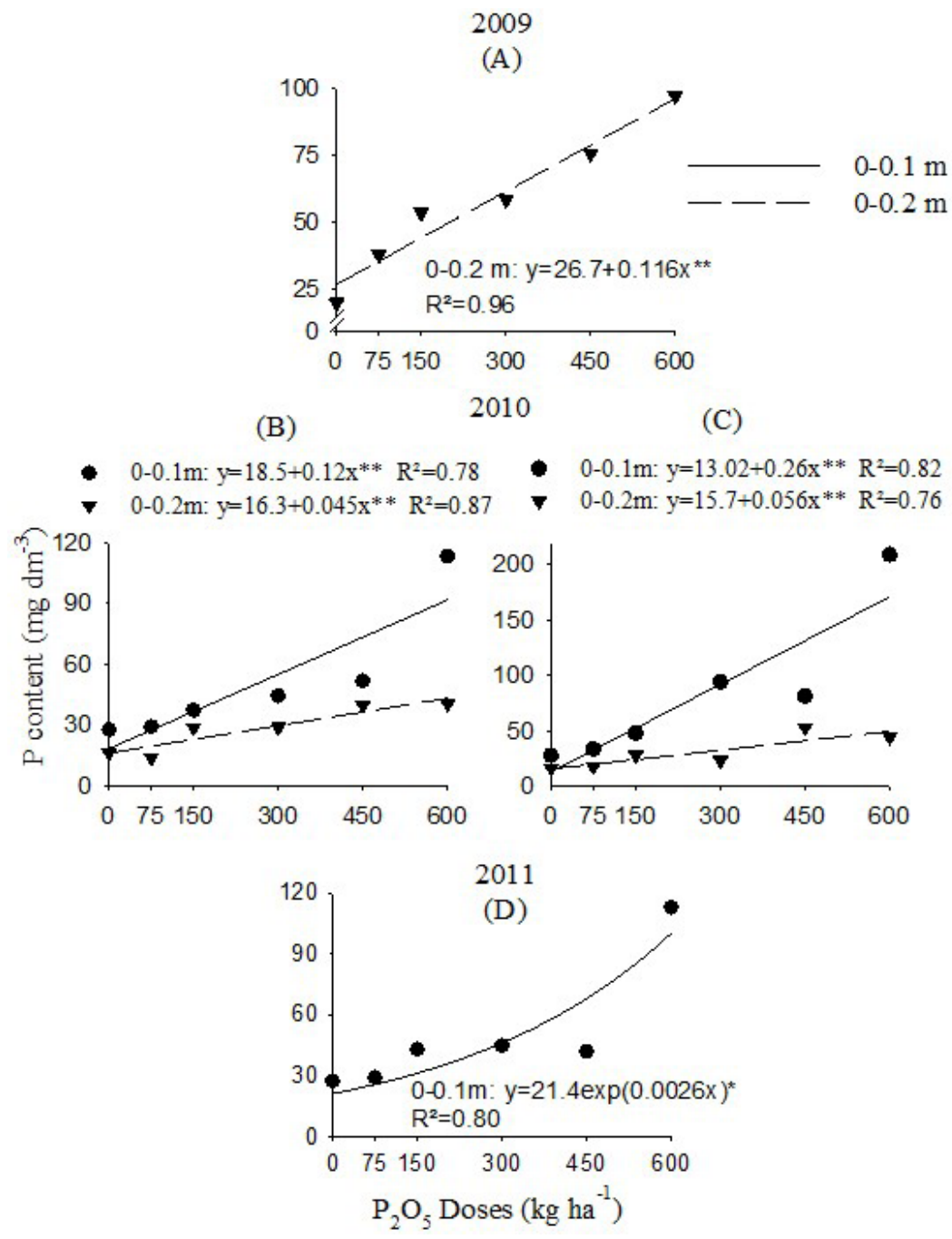

Figure 2: Soil available P measured with ion exchange resin at depths of 0-0.1 and 0-0.2 $\mathrm{m}$ in a Red Argisol (Ultisol) of Três Pontas, MG, as a function of the annual surface applications of sources and doses of phosphorus in samples collected in 2009, 2010 and 2011. A, B and D: simple superphosphate source; C: thermal phosphate source.

Significant (t test) at $* 5 \%$ and $* * 1 \%$.

results were found by Reis et al. (2011) in irrigated coffee in Planaltina, DF, where leaf $\mathrm{P}$ content stabilized at $1.98 \mathrm{~g}$ $\mathrm{kg}^{-1}$ starting from a dose of $270 \mathrm{~kg}$ ha $\mathrm{P}_{2} \mathrm{O}_{5}$.

Note that in this sampling phase, the highest leaf $P$ content was found in coffee plants that were adequately nourished (Laviola et al., 2007). In the same study, Laviola et al. (2007) found that P levels decreased as the nutrient dose increased. Those authors explained their results in terms of the increasingly strong effect of the fruit sink caused by the higher yields resulting from $\mathrm{P}$ application. Gallo et al. (1999) found an increase in leaf P concentration as they increased $\mathrm{P}$ doses from 30 to $90 \mathrm{~kg} \mathrm{ha}^{-1}$ of $\mathrm{P}_{2} \mathrm{O}_{5}$.
Several authors have determined an adequate leaf P content for coffee: 1.2 to $1.6 \mathrm{~g} \mathrm{~kg}^{-1}$ (Guimarães et al., 1999, Martinez et al., 2004), 1.2 to $2.0 \mathrm{~g} \mathrm{~kg}^{-1}$ (Mills; Jones Jr., 1996), and 1.6 to $2.0 \mathrm{~g} \mathrm{~kg}^{-1}$ (Malavolta et al. 1997).

In the control treatment $\left(0 \mathrm{~kg} \mathrm{ha}^{-1} \mathrm{P}_{2} \mathrm{O}_{5}\right)$, except in 2009, the leaf $P$ content was within the range suggested by most authors, most likely due to $\mathrm{P}$ application in the planting hole. In the other treatments, in which the highest yields were obtained, the leaf $\mathrm{P}$ content was above the level considered adequate according to Guimarães et al. (1999) and Martinez et al. (2004). Based on the results of this study and on the findings of Reis et al. (2011), where the leaf P 


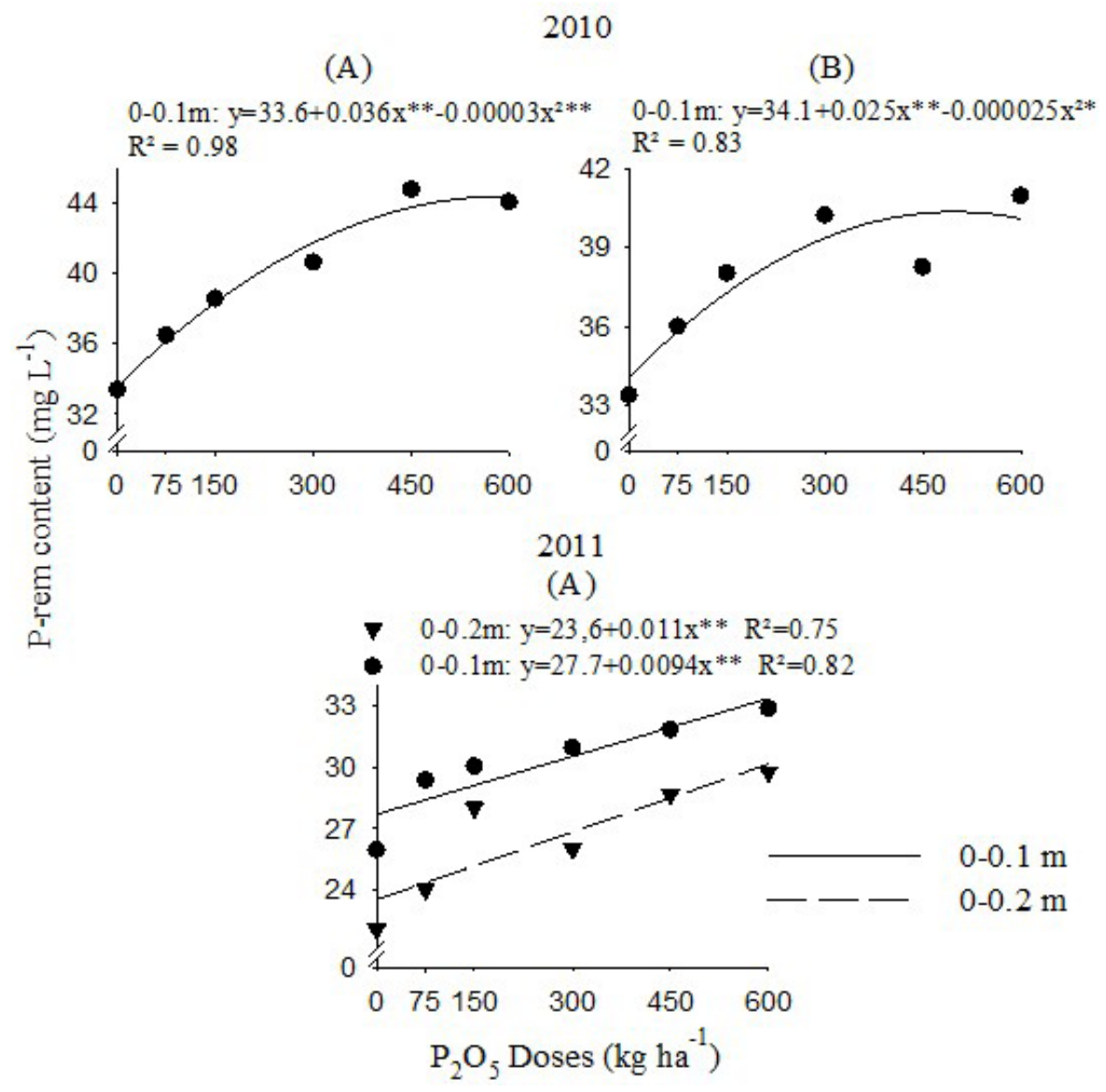

Figure 3: Remaining soil phosphorus content (P-rem) at depths of 0-0.1 $\mathrm{m}$ and $0-0.2 \mathrm{~m}$ in a Red Argisol (Ultisol) of Três Pontas, MG, as a function of annual surface applications of sources and doses of phosphorus in samples collected in 2010 and 2011. A and C: simple superphosphate source; B: thermal phosphate source.

Significant (t test) at $* 5 \%$ and $* * 1 \%$.

content corresponding to higher yields was greater than $1.8 \mathrm{~g} \mathrm{~kg}^{-1}$, the lower limit of the range considered ideal by most authors is evidently too low. Thus, the results obtained in the present study, obtained from the field and based on several years of evaluation, allow the recommendation that to achieve an average productivity greater than $55 \mathrm{bags} \mathrm{ha}^{-1}$, the critical leaf $\mathrm{P}$ content must be greater than $1.8 \mathrm{~g} \mathrm{~kg}^{-1}$.

In a study by Corrêa et al. (2001), an analysis of 75 leaf samples taken from coffee crops in Southern Region of MG found that $49.3 \%$ showed a foliar P content of less than $1.6 \mathrm{~g} \mathrm{~kg}^{-1}$. These results support the hypothesis that low levels of this nutrient may be limiting productivity in this region.

\section{Productivity}

Except for magnesium thermal phosphate in 2009 and production in the biennium 2009-2010 (Figures
5B and 5D), yields behaved linearly as a function of $\mathrm{P}$ application (Figures 5A, 5C and 6). In 2009, for magnesium thermal phosphate, maximum productivity (49.4 bags of processed coffee ha ${ }^{-1}$ ) was obtained with the application of $422.7 \mathrm{~kg} \mathrm{ha}^{-1} \mathrm{P}_{2} \mathrm{O}_{5}$, and production corresponding to maximum economic efficiency (44.46 bags $\mathrm{ha}^{-1}$ ) was obtained with the application of $189 \mathrm{~kg}$ ha $^{-1} \mathrm{P}_{2} \mathrm{O}_{5}$, providing an increase of approximately $38 \%$ in productivity compared with the control (Figure 5B). Note that the control also had good yields for a rainfed crop. This response may have been due, in part, to the effective management of the crop and the P fertilization at planting applied in the hole, avoiding the subsequent sampling and not reflecting the $\mathrm{P}$ content observed in the soil analysis because the sampling was performed on the canopy projection and not at the planting hole. 


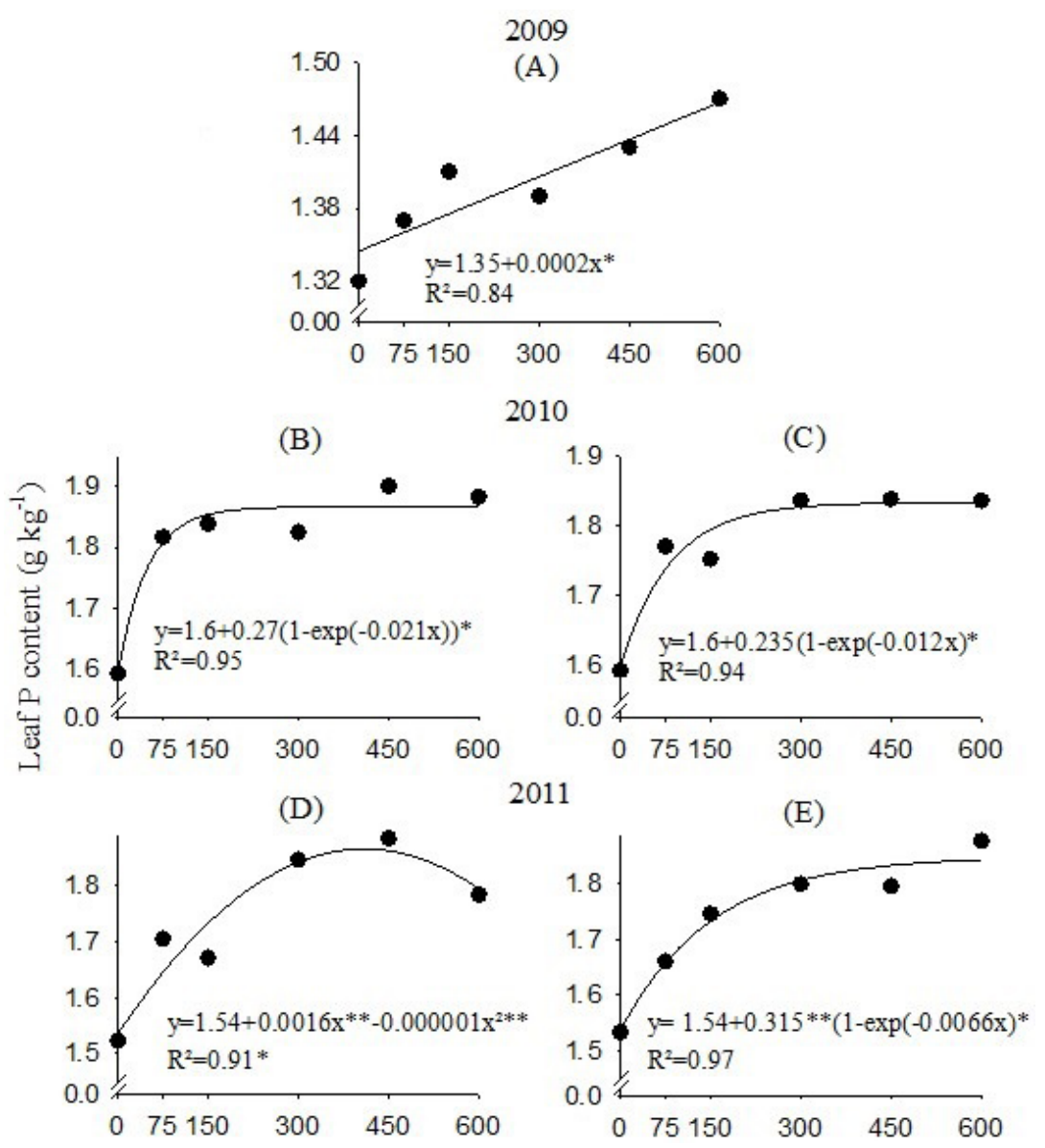

Figure 4: Leaf $P$ content in coffee as a function of annual surface applications of sources and doses of phosphorus in samples collected in 2009, 2010 and 2011. A, B and D: simple superphosphate source; C and E: thermal phosphate source. *Significant ( $\mathrm{t}$ test) at $5 \%$.

Several field studies have shown positive responses of coffee to P application. Gallo et al. (1999) observed an increase in coffee yield of approximately $16 \%$ in soils with low phosphorus with the application of $90 \mathrm{~kg} \mathrm{ha}^{-1}$ of $\mathrm{P}_{2} \mathrm{O}_{5}$ as triple superphosphate. Moreover, a $12 \%$ increase in productivity was also obtained by Prezotti and Rocha (2004). More marked productivity increases in response to fertilization with high levels of $\mathrm{P}$ during the production phase were observed by Guerra et al. (2007) and Reis et al. (2011), who found increases of up to $73.4 \%$ and $138 \%$, respectively, in irrigated coffee in an Oxisol (Latosol) originally under cerrado in Planaltina, DF. In all seven harvests evaluated in those two studies, productivity responses were linear up to the maximum dose studied, showing that coffee in the production phase responds to fertilization with $\mathrm{P}$ and that this nutrient must be applied due to soil drainage and plant energy demands (Reis et al., 2011).

Mera et al. (2011), studying phosphorus fertilization under different water regimes in coffee under production planted in an Oxisol (Latosol) originally under cerrado, observed that without artificial watering for 70 days, a dose of $400 \mathrm{~kg} \mathrm{ha}^{-1} \mathrm{P}_{2} \mathrm{O}_{5}$ (the maximum dose studied) provided the highest vegetative growth and a higher yield. The authors also emphasized that this dose was not sufficient to express the maximum yield potential, suggesting the possible use of higher doses.

Studies conducted with various cultures have shown positive contributions to productivity by $\mathrm{P}$ supplied via thermal phosphates, which have proven to be as efficient as water-soluble fertilizer (Goedert; Lobato, 1984; Malavolta; Moreira, 2001). These results have been explained by the efficiency of the P supply and, 


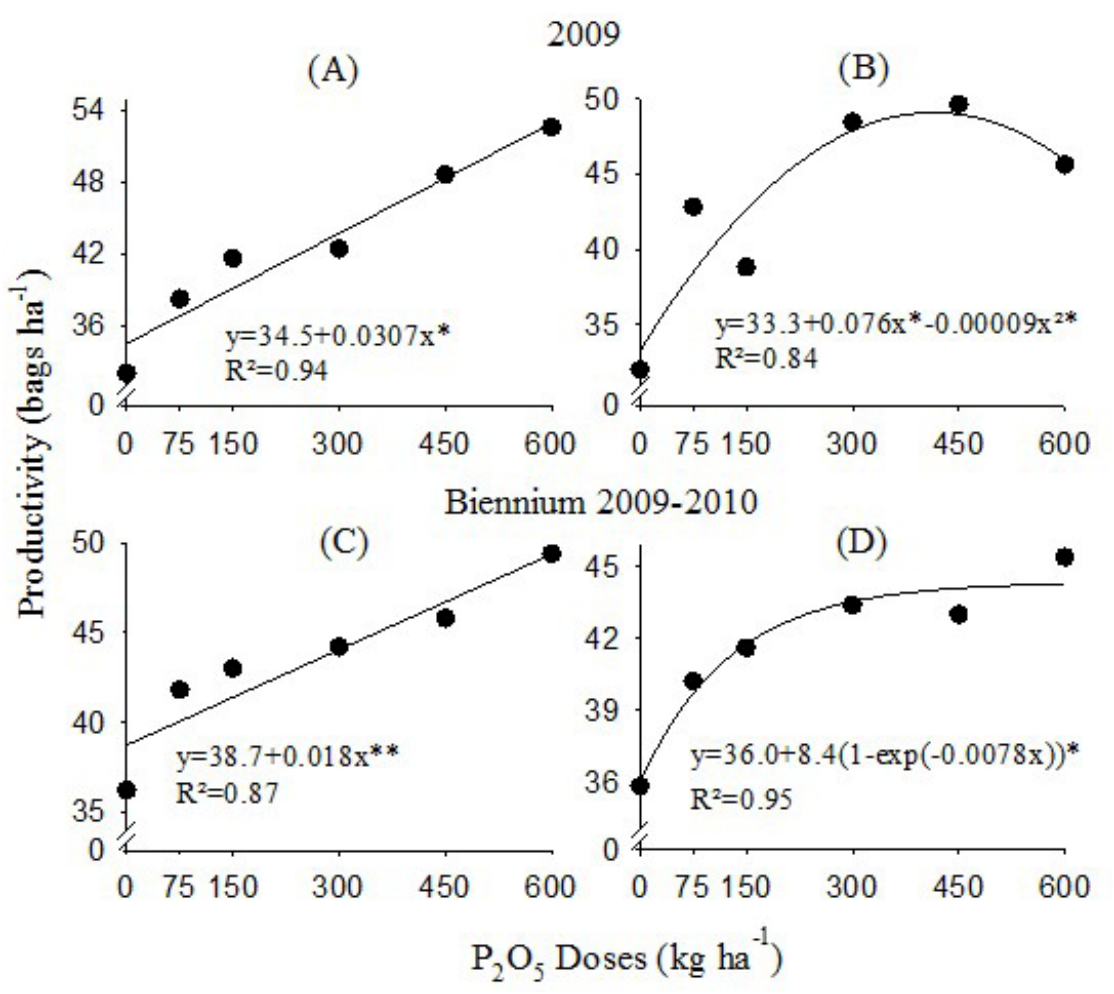

Figure 5: Coffee yield as a function of annual surface applications of $\mathrm{P}$ sources and doses in 2009 and production in the biennium 2009-2010. A and C: simple superphosphate source; B and D: thermal phosphate source.

Significant ( $\mathrm{t}$ test) at $* 5 \%$ and $* * 1 \%$.

additionally, by the nutritional and corrective effects of $\mathrm{Ca}$ and $\mathrm{Mg}$ silicates present in these materials. Melo et al. (2005) found positive responses in coffee to the application of thermal phosphate to the plantation.

The increase in productivity resulting from the use of simple superphosphate, based on the average of the three harvests $(2009,2010$ and 2011), was $45.3 \%$, or 18 bags ha $^{-1}$. The corresponding increase in productivity resulting from the use of thermal phosphate was $40.3 \%$, or 16 bags ha $^{-1}$. The thermal phosphate treatment resulted in an AEI of $89 \%$, on average, for the three years of production; moreover, the AEI was $101.38 \%$ in 2011 (Figure 6D).

According to Guerra et al. (2006), the phosphorus in coffee crops under production must serve as an energy source for the growth of new branches in support of future harvests and should not only support the grain harvest currently in the process of formation. These authors also indicate that an annual dose of $300 \mathrm{~kg} \mathrm{ha}^{-1} \mathrm{P}_{2} \mathrm{O}_{5}$ is needed to maintain the growth of the vegetative and reproductive branches and furnish an average yield of 60-70 bags ha-1.
Based on the average of the three harvests evaluated in this study, there were no significant differences between the yields obtained by applying the two sources at any of the doses evaluated. However, the thermal phosphate appears to supply the available $\mathrm{P}$ to the plants more gradually than the simple superphosphate because no response in leaf $\mathrm{P}$ content to thermal phosphate application was observed in 2009 (first year of assessment) and because a weaker response of coffee productivity was observed during the same year.

The data of this study and the findings presented by Reis et al. (2011) comprise results from three P sources (triple superphosphate, simple superphosphate and magnesium thermal phosphate), eight doses of $\mathrm{P}_{2} \mathrm{O}_{5}$ $\left(0,75,100,150,200,300,450\right.$ and $\left.600 \mathrm{~kg} \mathrm{ha}^{-1}\right)$ and several years of field evaluation. In all of these trials, linear responses by the coffee were demonstrated up to the maximum doses studied. This behavior indicates that for the modern and technically advanced coffee culture currently practiced in various regions of Brazil, there 


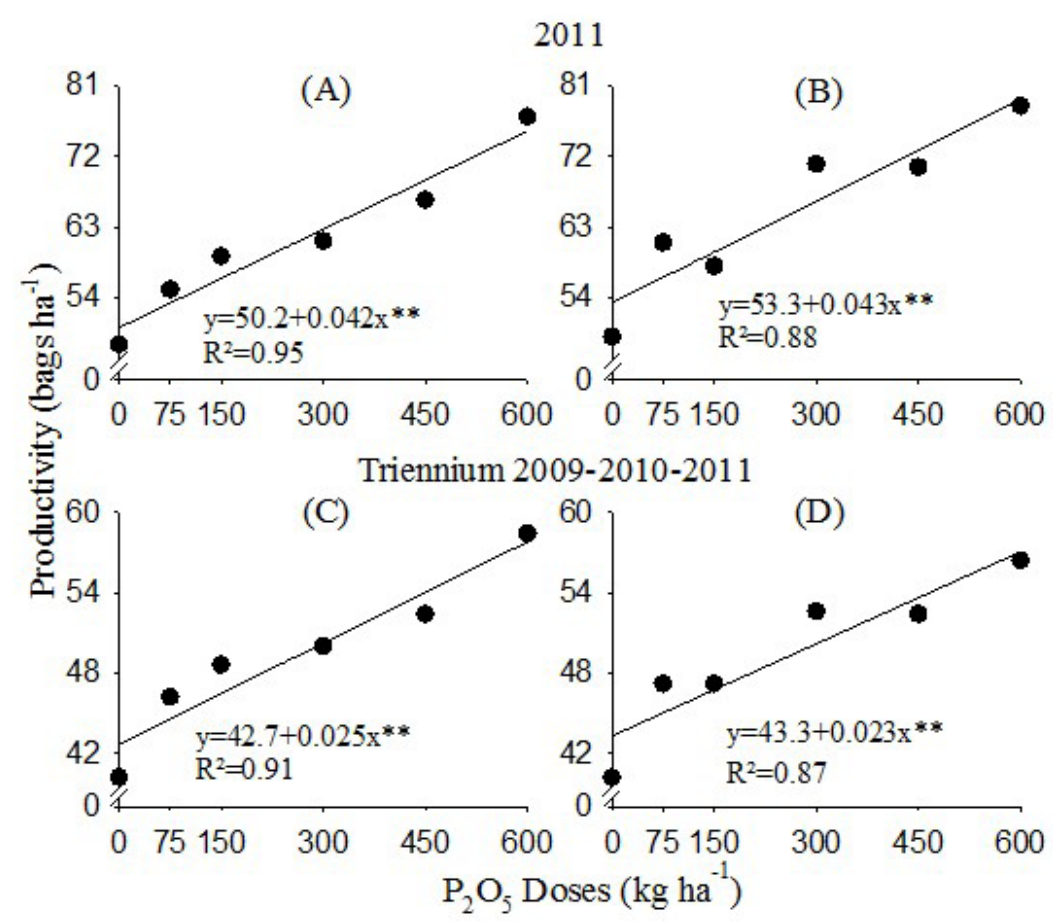

Figure 6: Coffee productivity as a function of the annual surface applications of sources and P doses in 2011 and production in the triennium 2009-2010-2011. A and C: simple superphosphate source; B and D: thermal phosphate source. Significant ( $\mathrm{t}$ test) at $* 5 \%$ and $* * 1 \%$.

appears to be no basis for the assertion that coffee in the production stage does not respond to fertilization because the crop does not need additional phosphorus. The energy demands of the plants, especially those with high yield potential, should be well understood to enhance the current knowledge of the P dynamics of coffee.

\section{CONCLUSIONS}

The coffee was responsive to fertilization in the production phase, with gains of $45.3 \%$ and $40.3 \%$ for simple superphosphate and thermal phosphate, respectively, for the application of the highest dose studied, $600 \mathrm{~kg} \mathrm{ha}^{-1} \mathrm{P}_{2} \mathrm{O}_{5}$, based on the average of the three crops.

The yield obtained in 2009 and in the 2009-2010 biennium as a result of the application of magnesium thermal phosphate stabilized at a dose of approximately $300 \mathrm{~kg} \mathrm{ha}^{-1} \mathrm{P}_{2} \mathrm{O}_{5}$.

Both sources studied, simple superphosphate and thermal phosphate, were similar and effective in supplying $P$ to the coffee.

The leaf $\mathrm{P}$ content increased with increases in the dose of nutrient applied to the soil for both sources, stabilizing at approximately 1.8 to $1.9 \mathrm{~g} \mathrm{~kg}^{-1}$.
The soil available $\mathrm{P}$ values, determined by Mehlich-1 extraction and ion exchange resin methodology, increased with increasing doses for the two sources studied.

\section{REFERENCES}

ALVAREZ, V. H. Correlação e calibração de métodos de análise de solos. In: ALVAREZ, V.H.; FONTES, L.E.F; FONTES, F.M.P. (Ed.). O solo nos grandes domínios morfoclimáticos do Brasil e o desenvolvimento sustentado. Viçosa, MG. Sociedade Brasileira de Ciência do Solo, 1996. p.615-645.

BATAGLIA, O. C. Resposta à adubação fosfatada na cultura do café. In: YAMADA, T.; ABDALLA, S. R. S. (Ed.). Fósforo na agricultura brasileira. Piracicaba: Potafos/Anda, 2004. p. 307-328.

CAIONE, G. et al. Produtividade e valor nutricional de variedades de cana-de-açúcar sob diferentes fontes de fósforo. Semina: Ciências Agrárias. 33(1):2813-2824, 2012. 
CHIEN, S. H.; HAMMOND, L. L. A comparison of various laboratory methods for predicting the agronomic potential of phosphate rocks for direct application. Soil Science Society of America Journal. 42(6):935-939, 1978.

COMPANIA NACIONAL DE ABASTECIMENTOCONAB. Acompanhamento da Safra Brasileira de Café Safra 2012: quarta estimativa. Brasília, 2012. Available in: <www.conab.gov.br $>$. Acesso em: 29 jan. 2013.

CONTE, E.; ANGHINONI, I.; RHEINHEIMER, D. S. Frações de fósforo acumuladas em latossolo argiloso pela aplicação de fosfato no sistema plantio direto. Revista Brasileira de Ciência do Solo. 27(5):893-900, 2003.

CORRÊA, J. B. et al. Avaliação da fertilidade do solo e do estado nutricional de cafeeiros do sul de Minas Gerais. Ciência e Agrotecnologia. 25(6):1279-1286, 2001.

\section{EMPRESA BRASILEIRA DE PESQUISA}

AGROPECUÁRIA. Manual de analises químicas de solos, plantas e fertilizantes. 2. ed. Brasília: Embrapa Informação Tecnológica, 2009.

FERREIRA, D. F. SISVAR: a computer statistical analysis system. Ciência e Agrotecnologia. 35(6):1039$1042,2011$.

GALLO, P. B. et al. Resposta de cafezais adensados à adubação NPK. Bragantia. 58(2):341-351, 1999.

GOEDERT, W. J. LOBATO, E. Avaliação agronômica de fosfatos em solo de cerrado. Revista Brasileira de Ciência do Solo. 8(1):97-102, 1984.

GUERRA, A. F. et al. Manejo da irrigação do cafeeiro, com estresse hídrico controlado, para uniformização de florada. In: ZAMBOLIM, L. (Ed.). Boas práticas agrícolas na produção de café. Viçosa, MG, 2006. Cap. 3, p. 83-115.

Sistema de produção de café irrigado: um novo enfoque. Item. (73):52-61, 2007.

GUIMARÃES, P. T. G. et al. Adubação do cafeeiro e a qualidade do produto colhido. Informe Agropecuário. 32(261):39-51, 2011.
GUIMARÃES, P. T. G.; RIBEIRO, C. R.; ALVAREZ; $\mathrm{V}$. V. H. Recomendações para o uso de corretivos e fertilizantes em Minas Gerais: $5^{\mathrm{a}}$ aproximação. Viçosa, MG: Comissão de Fertilidade do Solo do Estado de Minas Gerais, 1999. p.289-302.

LAVIOLA, B. G. et al. Dinâmica de P e S em folhas, flores e frutos de cafeeiro arábico em três níveis de adubação. Bioscience Journal. 23(1):29-40, 2007.

MALAVOLTA, E. Manual de nutrição mineral de plantas. São Paulo: Agronômica Ceres, 2006. 631p.

MALAVOLTA, E.; VITTI, G. C.; OLIVEIRA, S. A. Avaliação do estado nutricional das plantas: princípios e aplicações. 2. ed. Piracicaba: POTAFOS, 1997. $319 \mathrm{p}$.

MARTINEZ, H. E. P. et al. Nutrição mineral, fertilidade do solo e produtividade do cafeeiro nas regiões de Patrocínio, Manhuaçu, Viçosa, São Sebastião do Paraíso e Guaxupé. Belo Horizonte: EPAMIG, 2004. 60 p. (Boletim Técnico, 72).

MELO, B. et al. Fontes e doses de fósforo no desenvolvimento e produção do cafeeiro, em um solo originalmente sob vegetação de cerrado de Patrocínio MG. Ciência e Agrotecnologia. 29(2):315-321, 2005.

MERA, A. C. et al. Regimes hídricos e doses de fósforo em cafeeiro. Bragantia. 70(2):302-311, 2011.

MILLS, H. A.; JONES JUNIOR, J. B. Plant analysis handbook II. 2nd ed. Athens: Micro-Macro, 1996. 422 p.

MOREIRA, A.; MALAVOLTA, E. Fontes, doses e extratores de fósforo em alfafa e centrosema. Pesquisa Agropecuária Brasileira. 36(12):1519-1527, 2001.

NACHIMUTHU, G. et al. Isotopic tracing of phosphorus uptake in corn from $\mathrm{P}$ labelled legume residues and P labelled fertilisers applied to a sandy loam soil. Plant and Soil. 314(1-2):303-310, 2009.

NOVAIS , R. F. de. et al. Fertilidade do solo. Viçosa: Sociedade Brasileira de Ciência do Solo, 2007. 1017p.

PREZOTTI, L. C. ROCHA, A. C. Nutrição do cafeeiro arábica em função da densidade de plantas e da fertilização com NPK. Bragantia. 63(2):239-251, 2004. 
RAIJ, B. et al. Análise química para avaliação da fertilidade de solos tropicais. Campinas: Instituto Agronômico, 2001. 285p.

RAIJ, B. et al. Recomendações de adubação e calagem para o Estado de São Paulo. Campinas:
Instituto Agronômico/Fundação IAC, 1997. 285p

(Boletim Técnico, 100).

REIS, T. H. P. et al. Soil phosphorus dynamics and availability and irrigated coffee yield. Revista Brasileira de Ciência do Solo. 35(2):503-512, 2011. 